\title{
undergraduate medical education
}

\section{Well-being in an academic environment}

\author{
Tracy STECKer
}

PURPOSE Due to the high volume and acuity of mental health issues presented by graduate and professional students nationwide, this study explored specific mental health needs in students in order to identify credible areas for intervention.

METHODS An assessment tool was created for this project, which identified satisfaction with current services, stress, coping, sleeping, eating, exercise, high risk sexual behaviours, social support, depression and substance use. Students at top ranking academic medical centres within the USA received a copy of the instrument on 2 separate occasions.

RESULTS Results indicated that graduate and professional students reported alarming symptoms of depression, stress and substance use. Increased symptoms of depression were associated with high levels of stress and low social support.

CONCLUSION Given the high rates of depression symptoms in this setting, along with inadequate services and long waiting lists, interventions must be found to address need. Need assessment is a proactive method of exploring need in specific populations in order to provide preventive and clinical services efficiently. Based on the relationship between stress, social support and symptoms of depression, forming groups aimed at preventing depression may be the best method of reducing the severity and frequency of symptoms in students.

KEYWORDS education, medical, continuing/*methods; mental health; *adaptation psychological; stress psychological/psychology/prevention and control;

University of Arkansas for Medical Sciences, Little Rock, Arkansas, USA Correspondence: Tracy Stecker PhD, 521 Jack Stephens \#530, University of Arkansas for Medical Sciences, Little Rock, Arkansas 72205, USA. Tel: 001 501.686.6630; Fax: 001 501.686.8421; E-mail: steckertracy@ uams.edu substance abuse/*psychology; risk factors; students, medical.

Medical Education 2004; 38: 465-478

doi:10.1046/j.1365-2929.2004.01812.x

\section{INTRODUCTION}

Stress during advanced academic training is inevitable. Stress has been associated with year in school; ${ }^{1}$ particular coping styles, such as escape/distancing; difficulty adjusting to medical school, ${ }^{2}$ and being in nursing school. ${ }^{3,4}$

Depression is a serious mental health risk in student populations. Research on depression in graduate and professional students indicates that students who are most at risk of depression are medical students, especially those in their second year, female, married and with children. ${ }^{5-9}$ Substance use is also a major mental health risk; however, due to feelings of vulnerability, students may not be accurately reporting usage. ${ }^{10}$

\section{Tool development}

Research on depression, substance use and levels of distress in student populations obligates mental health professionals to study patterns of distress on campuses in order to promote health and wellness and to intervene appropriately when necessary. Coincidentally, there has been a recent increase in the volume and acuity of psychiatric need in student populations. In order to study need, a valid and reliable tool is required. For the purpose of this study, medical schools across the country were contacted in order to determine which assessment instrument was normally used to assess need in students. Responses indicated that most schools either developed their own tool, which was not psychometrically valid, or did not use such a tool. After a thorough review of the 


\section{Key learning points}

Graduate and professional students report high rates of depression, stress and substance use.

Depression was predicted by levels of perceived stress and social support.

Groups aimed at preventing depression may be the best way to treat symptoms of depression in this population.

literature and instruments previously used to assess need, it was decided that a more comprehensive instrument was required. The tool was developed after multiple focus groups with students and mental health professionals had been held. Items were developed based on the literature review, focus groups and review of previously used assessment tools. The tool underwent several revisions as it was analysed by several professional groups on campus. Finally, a pilot study of the tool was carried out with a group of postdoctoral fellows.

\section{Purpose}

The purpose of this study was to distribute the questionnaire on 2 separate occasions to assess specific psychiatric needs in graduate and professional students in order to identify areas for intervention.

\section{METHODS}

An assessment tool measuring several aspects of health and wellness was designed for this study. Aspects assessed included demographic information, satisfaction with SHS, stress, coping, sleeping, eating, exercise, high risk sexual behaviours, social support, depression and substance use. The questionnaire required approximately 20-30 minutes to complete. Students at a top ranking academic medical centre in the USA received a copy of the questionnaire and an informed consent form and were asked to return both in an enclosed addressed and stamped envelope. ${ }^{11}$ The questionnaire was distributed twice. The first distribution went to all graduate and professional students during the summer of 2001. Distribution occurred through a mass mailing either directly to their home addresses or to their boxes at school. Differences in distribution were due to specific suggestions from department chairs. The second distribution occurred during the transition between the winter and spring quarters in 2002. All schools again received the questionnaire except for medical students.

Stress was broken down into 4 subscales assessing academic, health, psychosocial and external stress. The following items assessed academic stress: coursework, performance, competition with peers, mentoring, interaction with faculty and commuting. The following items assessed health stress: alcohol and drug use, eating, illness, sexual difficulties, sleeping difficulties, physical limitations and pregnancy. Psychosocial stress was assessed by items on family difficulties, grief or bereavement, time for recreation, living or roommate situations, loneliness, prejudice, relationship difficulties, and socialising. External stress was assessed by financial strain, changes in residence, job dissatisfaction, legal difficulties and other issues. Respondents were asked to rate the frequency of stress on a scale of $1-5$ and the severity of stress on a scale of 1-10 for each of these items.

Coping skills were assessed by having respondents identify 10 coping skills that they used to deal with stress and indicate how effective they believed each skill was in dealing with their stress on a scale of $1-5$.

Depression was assessed by having respondents report how frequently they had experienced symptoms of depression, as identified by the Diagnostic and Statistical Manual for Mental Disorders, 4th Edition (DSM-IV), ${ }^{12}$ over the previous 4 weeks. Substance use was assessed by having students indicate how frequently they used each drug listed. Drugs included cocaine, amphetamines, barbiturates, crystal methamphetamine, ecstasy, GHB, hallucinogens, opiates, tranquillisers, caffeine, nicotine and alcohol. Respondents were also asked to report how much alcohol they consumed during a typical drinking occasion.

\section{RESULTS}

\section{Distribution 1}

The first distribution of the questionnaire occurred during the summer of 2001. Graduate students were more likely to be around during the summer 
Table 1 Demographic information for respondents to distribution 1 . Respondents were aged 21-54 years (mean age 28.7 years)

$\begin{array}{lr}\text { Category } & n \\ \text { Gender } & \\ \text { Male } & 115 \\ \text { Female } & 338 \\ \text { Marital status } & \\ \text { Single } & 267 \\ \text { Married } & 105 \\ \text { Ethnicity } & \\ \text { White } & 268 \\ \text { African American } & 6 \\ \text { Hispanic } & 19 \\ \text { Asian } & 129 \\ \text { Middle Eastern } & 15 \\ \text { School } & \\ \text { Pharmacy } & 87 \\ \text { Physical therapy } & 25 \\ \text { Dentistry } & 24 \\ \text { Medicine } & 114 \\ \text { Nursing } & 123 \\ \text { Graduate } & 69 \\ \text { Year in school } & \\ \text { Year 1 } & 74 \\ \text { Year 2 } & 14 \\ \text { Year 3 } & 96 \\ \text { Year 4 } & 97 \\ \text { Year 5 } & 14 \\ \text { Year 6 } & 11\end{array}$

months, whereas students in other schools had the option to take the summer off. Therefore, we anticipated a low response rate for the majority of students except graduate students. A total of 461 students responded to the questionnaire, giving a return rate of $20 \%$. Demographic information is provided in Table 1.

Of this sample, $18 \%$ reported seeking mental health counselling at SHS. Comparable rates existed for all students, except for students in the graduate school. A total of $29 \%$ of graduate students sought mental health services. An additional $20 \%$ of the overall sample indicated that they would have liked to seek services, but had not for various reasons. The most common reasons reported for not seeking services were limitations (long waiting lists, access issues, scheduling problems), lack of awareness that services were available, services sought outside university, time constraints, stigma, and improved circumstances. Additional mental health services were also widely requested by students: $44 \%$ requested more individual counselling services, $53 \%$ requested additional stress/relaxation services, and $28 \%$ requested group therapy options.

\section{Depression}

An alarming number of students reported significant symptoms of depression during the previous 4-week period. A total of $25 \%$ of all respondents, regardless of school, ethnicity or gender, reported a score on the depression scale (12 or higher) that may be indicative of depression (school $\mathrm{F}=0.890$, $P=0.488$; ethnicity $\mathrm{F}=0.327, P=0.860$; and gender $\mathrm{F}=2.007, P=0.157)$. At least 5 symptoms of depression were reported by $10 \%$ of students. Suicidal thoughts were reported by $10 \%$ of the sample $(n=44)$, and having a specific plan for suicide was reported by $2 \%(n=9)$. The breakdown of depression scores is reported in Table 2.

Table 2 Depression results from respondents to distribution 1

$\begin{array}{lrllcll} & n & \text { Mean } & \begin{array}{l}\text { Score of } 12 \\ \text { or more }\end{array} & \begin{array}{l}5 \text { or more } \\ \text { symptoms }\end{array} & \begin{array}{l}\text { Mean } \\ \text { support }\end{array} & \begin{array}{l}\text { Mean } \\ \text { stress }\end{array} \\ \text { Physical therapy } & 35 & 11.29 & 24 \% & 6 \% & 14.91 & 247.5 \\ \text { Pharmacy } & 87 & 11.17 & 22 \% & 12 \% & 13.52 & 248.9 \\ \text { Dentistry } & 24 & 11.48 & 24 \% & 5 \% & 13.23 & 234.6 \\ \text { Medicine } & 114 & 11.60 & 26 \% & 10 \% & 14.81 & 240.4 \\ \text { Nursing } & 123 & 11.30 & 27 \% & 10 \% & 14.84 & 285.2 \\ \text { Graduate } & 69 & 11.39 & 26 \% & 8 \% & 13.78 & 235.6 \\ \text { All } & 453 & 11.39 & 25 \% & 10 \% & 14.34 & 253.7\end{array}$


A regression analysis was run in order to determine which factors were related to depression. The regression analysis revealed that total stress scores accounted for $25 \%$ of the overall variance in depression $\left(r^{2}=0.264, P<0.000\right)$. Social support accounted for an additional $9 \%$ of the variance $\left(r^{2}=0.090\right.$,

$P<0.000)$. Therefore, impacting students on a group level and offering resources to deal with stress may help students become more resistant to depression.

\section{Substance use}

Students reported a wide range of substance use. Alcohol use was reported by $80 \%$ of the sample. Illegal drug use was reported by $19 \%$ of the sample. The majority of reported drug use concerned marijuana. Poly drug use was reported by $8 \%$ of the sample.

\section{Distribution 2}

Demographic information for distribution 2 is shown in Table 3. There were fewer participants in the second distribution of this questionnaire, which occurred during the transition between the winter and spring quarters. This may be due to respondents' having had a shorter time frame in which to return questionnaires. Furthermore, medical students were not offered a second distribution of the questionnaire due to timing issues. The 4 medical students who did respond to the questionnaire received a copy through their work in the graduate school and should not be regarded as representative of medical students.

Despite a smaller sample, students indicated similar rates of use of mental health services as in the first distribution. A total of $25 \%$ reported seeking mental health services at SHS during the past year. The rate was slightly higher than in the first distribution, which may have been due to the timing of the survey, which occurred mid-year as opposed to during the summer. Therefore, students may have been more stressed and more likely to admit to seeking services. Again, 19\% of students reported that they would have liked to schedule a visit, but had not for various reasons. Stated reasons for not scheduling the visit included time constraints, length of waiting lists, embarrassment, confidentiality, etc.

\section{Depression}

Depression scores continued to be distressing in that $35 \%$ of the sample reported a score of 12 or more on
Table 3 Demographic information for respondents to distribution 2. Respondents were aged $20-57$ years (mean age 30.4 years)

$\begin{array}{lr}\text { Category } & n \\ \text { Gender } & \\ \text { Male } & 36 \\ \text { Female } & 155 \\ \text { Marital status } & \\ \text { Single } & 117 \\ \text { Married } & 56 \\ \text { Ethnicity } & \\ \text { White } & 112 \\ \text { African American } & 3 \\ \text { Hispanic } & 8 \\ \text { Asian } & 17 \\ \text { Middle Eastern } & 6 \\ \text { School } & \\ \text { Pharmacy } & 24 \\ \text { Physical therapy } & 0 \\ \text { Dentistry } & 38 \\ \text { Medicine } & 4 \\ \text { Nursing } & 91 \\ \text { Graduate } & 35 \\ \text { Year in school } & \\ \text { Year 1 } & 68 \\ \text { Year 2 } & 50 \\ \text { Year 3 } & 33 \\ \text { Year 4 } & 20 \\ \text { Year 5 } & 74 \\ \text { Year 6 } & \\ & \end{array}$

the depression scale. No differences in depression were reported for school $(F=1.463, P=0.215)$, ethnicity $(F=1.115, P=0.351)$ or gender $(F=0.944, P=0.332)$. A total of $10 \%$ of the sample reported experiencing at least 5 symptoms of depression during the previous 4 weeks. Regression analyses indicated that total stress and social support were predictive of depression scores $\left(r^{2}=0.231\right.$, $P=0.000$ and $r^{2}=0.064, P=0.000$, respectively). Suicidal thoughts were acknowledged by $9 \%$ of the sample and a plan for suicide reported by $4 \%$. Data on depression scores are reported in Table 4.

\section{Substance use}

Substance use continued to be reported at high rates. Alcohol use was reported by $77 \%$ of the sample. 
Table 4 Depression results from respondents to distribution 2

$\begin{array}{lrrlcll} & n & \text { Mean } & \begin{array}{l}\text { Score of } 12 \\ \text { or more }\end{array} & \begin{array}{l}5 \text { or more } \\ \text { symptoms }\end{array} & \begin{array}{l}\text { Mean } \\ \text { support }\end{array} & \begin{array}{l}\text { Mean } \\ \text { stress }\end{array} \\ \text { Pharmacy } & 28 & 12.52 & 40 \% & 18 \% & 14.18 & 262.67 \\ \text { Dentistry } & 40 & 12.28 & 45 \% & 10 \% & 14.30 & 272.72 \\ \text { Medicine } & 4 & 9.00 & 0 \% & 0 \% & & \\ \text { Nursing } & 95 & 12.16 & 37 \% & 10 \% & 14.78 & 268.61 \\ \text { Graduate } & 39 & 11.38 & 19 \% & 5 \% & 14.50 & 253.45 \\ \text { All } & 206 & 12.02 & 35 \% & 10 \% & 14.48 & 265.32\end{array}$

Illegal drug use was reported by $25 \%$ of the sample. The most commonly used drug was marijuana, with $84 \%$ of drug use reported as marijuana use.

\section{Stress and coping}

Four subscales assessed frequency and severity of stress. These subscales included academic, health, psychosocial, and external stress. Respondents were asked to rate frequency of stress on a scale of 1-5 and severity on a scale of 1-10. Results from the stress indices were similar in both distributions and are reported together. Students reported high rates of stress.

There were no school differences reported overall on stress, although nursing students reported higher stress scores on academic and external stresses $(F=2.48, P=0.031$ and $\mathrm{F}=4.50, P=0.001$, respectively) (Figure 1 ). This may be due to the higher likelihood that nursing students had outside employment during their academic training, leading to less time for studying and more job and financial stress. Females reported significantly higher stress on all scales except external stress (academic $\mathrm{F}=5.528$, $P=0.019$; health $\mathrm{F}=8.959, P=0.003$; psychosocial $\mathrm{F}=4.315, P=0.038 ;$ external $\mathrm{F}=0.286, P=0.593)$.

Students were asked to report the coping skills they used to deal with stress. They were also asked to indicate how effective they believed the skill was for dealing with their stress. Results were almost identical in both surveys and are reported together. Results indicated the 5 most commonly reported coping skills to be talking to friends, exercising, talking to family, watching TV or movies and play or recreation. Coping skills that were considered ineffective included acting angry, complaining, not thinking about the problem, thinking of the worst and altering eating habits.

Factor analysis of coping responses illuminates an interesting pattern. These factors do not clearly discriminate from each other, however, and should be
Figure 1 School differences: total and academic stress.

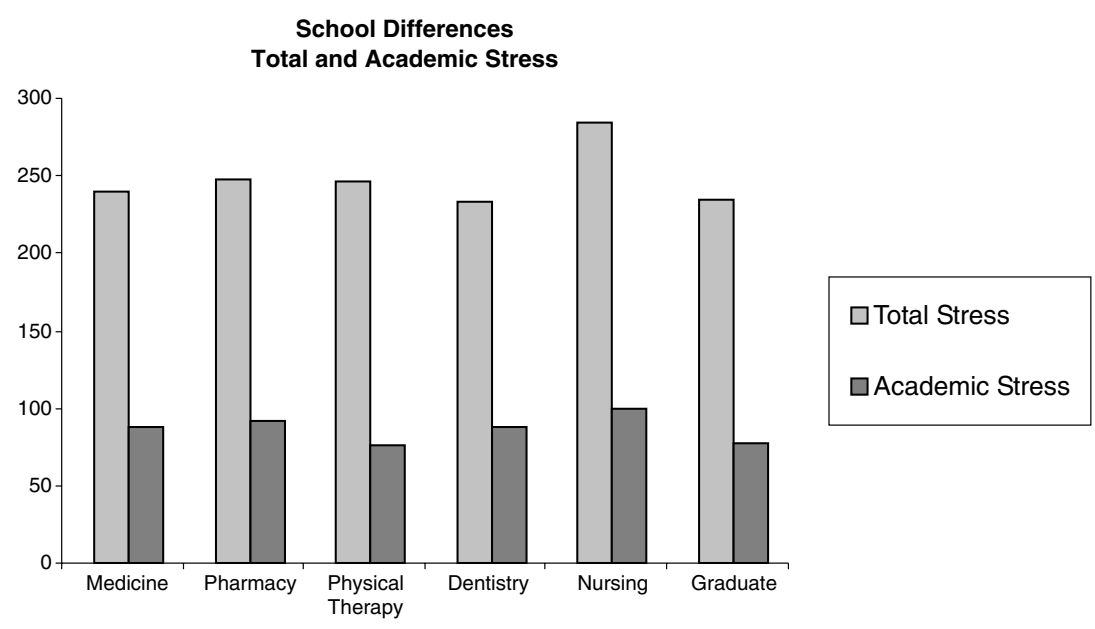


understood as a possible combination of coping styles. Five factors found included an expressive coping style (complaining, crying, being alone, altering sleep patterns and rationalising), a cognitive coping style (problem solving, not thinking about problems and looking at the big picture), an escapist style (yoga, watching TV or movies, altering sleep and eating habits), a social support style (talking with friends and family and exercising), and a hedonistic style (using drugs and alcohol, sex, humour and sports).

\section{CONCLUSIONS}

Students reported alarming symptoms of depression. According to this assessment, 25-35\% of students in advanced academic training may be experiencing depression.

Without adequate resources with which to deal with them, such symptoms could potentially be devastating to an academic career, if not fatal. Students reported both thoughts of death and plans for suicide. Although the rates of endorsement for these items were low, health professionals have an obligation to offer aid when an individual presents in need.

Psychiatric services need to be available to assist students in need, although financial resources for these programmes are not widely available. Health science students reported feeling vulnerable when presenting with mental health issues at SHS. They reported concerns that they might be seen by their peers in the waiting room or that they might be treated by peers or professors, and they worried that faculty awareness of a psychiatric diagnosis might impede their academic progress.

It is important to state that a significant score on this depression scale was determined to be a score of 12 or higher on the depression subscale. Depression was also coded if a respondent reported at least 5 symptoms in the previous 4 weeks. Without a clinical interview, it cannot be determined whether individuals were clinically depressed. These values were reported as indicating a need for further screening.

It should also be stated that clinically depressed individuals may not have the energy or desire to complete this type of intensive assessment instrument. Therefore, we may have missed some clinically depressed individuals. While missing some individuals, it is more likely that we hit individuals with less severe symptomatology. These individuals may be more likely to have the energy and desire to follow through with treatment recommendations, if they are available.

This assessment found that perceived levels of stress and social support predicted depression scores in both distributions. This relationship suggests that one way to treat depression in this population may be in group settings. ${ }^{13,14}$ This would allow students with similar academic workloads and personal difficulties to process issues together. Group processing could therefore relieve feelings of social isolation while at the same time providing treatment for symptoms of depression. For example, a student feeling hopeless regarding his or her future may deduce that he or she will not survive academic training. In this type of group setting, that student could hear from others with similar fears. Hopelessness could be processed as a symptom to address with the support of others. Further research should be done on groups aimed at preventing depression to assess their efficacy.

Finally, the psychometric properties of this instrument have not been fully tested. This instrument went through multiple levels of revision during development, and was piloted on a sample of postdoctoral fellows. Test-retest reliability may prove to be reliable as both distributions resulted in similar patterns. Validity has not been assessed, although the results of the survey coincide with a marked increase in the frequency and severity of mental health issues presented at SHS in this academic institution during 2000-02. Health professionals at SHS were unable to meet the needs of students calling in, and there was a rise in psychiatric hospitalisations during that time. In a typical year, 1 or 2 students at this institution are hospitalised but in the 2000-01 academic year, 17 students were hospitalised. Therefore, we would expect to find a higher than normal representation of stress, depression and substance use as found in this survey. It is unclear what contributed to this rise in severity and frequency of psychiatric need. Understanding causes of mental health need in students and providing efficacious and cost-effective services may begin to resolve this issue.

\section{ACKNOWLEDGEMENTS}

None.

FUNDING

None. 


\section{ETHICAL APPROVAL}

Ethical approval for this study was granted by the Internal Review Board at the University of California, San Francisco.

\section{REFERENCES}

1 Supe A. A study of stress in medical student at Seth GS Medical College. Med Educ 1998;44:1-6.

2 Schreier A, Abramovitch H. American medical students in Israel: stress and coping. Med Educ 1996;30:445-52.

3 Jones M, Johnston D. Distress, stress and coping in first year student nurses. Adv Nurs 1997;26:475-82.

4 Beck D, Hackett M, Srivastava R, McKim E, Rockwell B. Perceived level and sources of stress in university professional schools. Nurs Educ 1997;36 (4):180-6.

5 Rosal M, Ockene I, Ockene J, Barrett S, Ma Y, Hebert J. A longitudinal study of students' depression at one medical school. Acad Med 1997;71 (11):1225-31.

6 Stewart S, Betson C, Marshall I, Wong C, Lee P, Lam T. Stress vulnerability in medical students. Med Educ 1995;29 (2):119-27.

7 Stewart S, Betson C, Lam T, Marshall I, Lee P, Wong C. Predicting stress in first year medical students: a longitudinal study. Med Educ 1997;31:163-8.
8 Stewart S, Lam T, Betson C, Wong C, Wong A. A prospective analysis of stress and academic performance in the first 2 years of medical school. Med Educ 1999;33:243-50.

9 Vaz R, Mbajiorgu E, Acuda S. A preliminary study of stress levels among first year medical students at the University of Zimbabwe. Cent Afr J Med 1998;44 (9):214-9.

10 Camatta C, Nagoshi C. Stress, depression, irrational beliefs and alcohol use and problems in a college student sample. Alcohol Clin Exp Res 1995;19 (1):142-6.

11 US News and World Report: America's best graduate schools 2004. http://www.usnews.com.

12 American Psychiatric Association. Diagnostic and Statistical Manual of Mental Disorders. 4th edn. Washington DC: APA 1994.

13 Yalom I. The Theory and Practice of Group Psychotherapy. 4th edn. New York: Basic Books 1995.

14 Munoz R. The Healthy Management of Reality. San Francisco: HMOR 2000.

Received 14 March 2003; editorial comments to author 2 May 2003, 2 July 2003; accepted for publication 11 September 2003 


\section{APPENDIX}

\section{Student Health Status Survey}

Demographics Section

Please answer the questions below by either filling in the appropriate bubble or writing in an answer on the blank line.

Age: Write age in boxes

Gender: Male $\square$ Female $\square$

Relationship or marital status

Number of dependants

$\square 0 \square 1 \square 2 \square 3 \square 4 \square 5$ or more

Ethnicity

Are you a non-resident, international student? Yes No

To which school are you registered?

$\square$ Physical Therapy

Pharmacy

$\square$ Dentistry/Dental

$\square$ Hygiene

$\square$ Medicine

$\square$ Nursing

$\square$ Graduate: Social/Behavioural Programme

Graduate: PIBS

Graduate: BioMedical Sciences

Year in school

$\square 1 \square 2 \square 3 \square 4 \square 5 \square 6$ or more 
Part I

Please check the box next to the most appropriate answer.

1. Please describe your relationship to Student Health Services (SHS) at your school.

$\square$ I have never been to SHS at my school

$\square$ I have been to SHS for TB skin test and immunisations only

I seek services for primary care 1-3 times per year

I seek services more than 3 times per year

2. Are you satisfied with the clinical care received from the providers at SHS?

Satisfied

Somewhat satisfied

Somewhat unsatisfied

Unsatisfied

3. Are you satisfied overall with the service you received at SHS?

$\square$ Satisfied

$\square$ Somewhat satisfied

Somewhat unsatisfied

Unsatisfied

4. Have you ever sought mental health counselling at SHS at your school?

$\square$ Yes

$\square$ No

5. Have you ever considered seeking mental health counselling at SHS, but never scheduled an appointment?

$\square$ Yes

$\square$ No

If yes, why did you not schedule an appointment? (please list)

6. If a friend needed help with their mental health, would you refer them to Student Health?

$\square$ Yes

$\square$ No 
7. Consult the list of stressors below. For each stressor listed at the left, indicate the FREQUENCY with which you experienced each stressor during the past year and the SEVERITY with which the stressor impacted you. Fill in the bubble under the appropriate answer.

\begin{tabular}{|c|c|c|c|c|c|c|c|c|c|c|c|c|c|c|}
\hline \multirow[b]{2}{*}{ Academic stressors } & \multirow[b]{2}{*}{ Never } & \multirow[b]{2}{*}{ Rarely } & \multirow[b]{2}{*}{ Sometimes } & \multirow[b]{2}{*}{ Often } & \multirow[b]{2}{*}{ Always } & \multicolumn{8}{|c|}{ Not severe } & \multirow{2}{*}{$\begin{array}{l}\text { Severe } \\
10\end{array}$} \\
\hline & & & & & & 12 & 3 & 4 & 5 & 6 & 7 & 8 & 9 & \\
\hline Academic coursework & $\square$ & $\square$ & $\square$ & $\square$ & $\square$ & $\square \square$ & $\square$ & $\square$ & $\square$ & $\square$ & $\square$ & $\square$ & $\square$ & $\square$ \\
\hline School performance & $\square$ & $\square$ & $\square$ & $\square$ & $\square$ & $\square \square$ & $\square$ & $\square$ & $\square$ & $\square$ & $\square$ & $\square$ & $\square$ & $\square$ \\
\hline Competition with peers & $\square$ & $\square$ & $\square$ & $\square$ & $\square$ & $\square \square$ & $\square$ & $\square$ & $\square$ & $\square$ & $\square$ & $\square$ & $\square$ & $\square$ \\
\hline Lack of mentoring & $\square$ & $\square$ & $\square$ & $\square$ & $\square$ & $\square \square$ & $\square$ & $\square$ & $\square$ & $\square$ & $\square$ & $\square$ & $\square$ & $\square$ \\
\hline Interaction with faculty & $\square$ & $\square$ & $\square$ & $\square$ & $\square$ & $\square \square$ & $\square$ & $\square$ & $\square$ & $\square$ & $\square$ & $\square$ & $\square$ & $\square$ \\
\hline Commuting to school/work & $\square$ & $\square$ & $\square$ & $\square$ & $\square$ & $\square \square$ & $\square$ & $\square$ & $\square$ & $\square$ & $\square$ & $\square$ & $\square$ & $\square$ \\
\hline
\end{tabular}

\begin{tabular}{|c|c|c|c|c|c|c|c|c|c|c|c|c|c|c|c|}
\hline \multirow[b]{2}{*}{ Health concerns } & \multirow[b]{2}{*}{ Never } & \multirow[b]{2}{*}{ Rarely } & \multirow[b]{2}{*}{ Sometimes } & \multirow[b]{2}{*}{ Often } & \multirow[b]{2}{*}{ Always } & \multicolumn{9}{|c|}{ Not severe } & \multirow{2}{*}{$\begin{array}{l}\text { Severe } \\
10\end{array}$} \\
\hline & & & & & & 1 & 2 & 3 & 4 & 5 & 6 & 7 & 8 & 9 & \\
\hline Alcohol or drug usage & $\square$ & $\square$ & $\square$ & $\square$ & $\square$ & $\square$ & $\square$ & $\square$ & $\square$ & $\square$ & $\square$ & $\square$ & $\square$ & $\square$ & $\square$ \\
\hline Eating concerns & $\square$ & $\square$ & $\square$ & $\square$ & $\square$ & $\square$ & $\square$ & $\square$ & $\square$ & $\square$ & $\square$ & $\square$ & $\square$ & $\square$ & $\square$ \\
\hline Illness & $\square$ & $\square$ & $\square$ & $\square$ & $\square$ & $\square$ & $\square$ & $\square$ & $\square$ & $\square$ & $\square$ & $\square$ & $\square$ & $\square$ & $\square$ \\
\hline Sexual difficulties & $\square$ & $\square$ & $\square$ & $\square$ & $\square$ & $\square$ & $\square$ & $\square$ & $\square$ & $\square$ & $\square$ & $\square$ & $\square$ & $\square$ & $\square$ \\
\hline Sleeping difficulties & $\square$ & $\square$ & $\square$ & $\square$ & $\square$ & $\square$ & $\square$ & $\square$ & $\square$ & $\square$ & $\square$ & $\square$ & $\square$ & $\square$ & $\square$ \\
\hline Physical limitations & $\square$ & $\square$ & $\square$ & $\square$ & $\square$ & $\square$ & $\square$ & $\square$ & $\square$ & $\square$ & $\square$ & $\square$ & $\square$ & $\square$ & $\square$ \\
\hline Pregnancy & $\square$ & $\square$ & $\square$ & $\square$ & $\square$ & $\square$ & $\square$ & $\square$ & $\square$ & $\square$ & $\square$ & $\square$ & $\square$ & $\square$ & $\square$ \\
\hline
\end{tabular}

\begin{tabular}{|c|c|c|c|c|c|c|c|c|c|c|c|c|c|c|c|}
\hline \multirow[b]{2}{*}{ Psychosocial concerns } & \multirow[b]{2}{*}{ Never } & \multirow[b]{2}{*}{ Rarely } & \multirow[b]{2}{*}{ Sometimes } & \multirow[b]{2}{*}{ Often } & \multirow[b]{2}{*}{ Always } & \multicolumn{9}{|c|}{ Not severe } & \multirow{2}{*}{$\begin{array}{l}\text { Severe } \\
10\end{array}$} \\
\hline & & & & & & 1 & 2 & 3 & 4 & 5 & 6 & 7 & 8 & 9 & \\
\hline Family difficulties & $\square$ & $\square$ & $\square$ & $\square$ & $\square$ & $\square$ & $\square$ & $\square$ & $\square$ & $\square$ & $\square$ & $\square$ & $\square$ & $\square$ & $\square$ \\
\hline Grief or bereavement & $\square$ & $\square$ & $\square$ & $\square$ & $\square$ & $\square$ & $\square$ & $\square$ & $\square$ & $\square$ & $\square$ & $\square$ & $\square$ & $\square$ & $\square$ \\
\hline Lack of time for recreation & $\square$ & $\square$ & $\square$ & $\square$ & $\square$ & $\square$ & $\square$ & $\square$ & $\square$ & $\square$ & $\square$ & $\square$ & $\square$ & $\square$ & $\square$ \\
\hline Living/roommate situation & $\square$ & $\square$ & $\square$ & $\square$ & $\square$ & $\square$ & $\square$ & $\square$ & $\square$ & $\square$ & $\square$ & $\square$ & $\square$ & $\square$ & $\square$ \\
\hline Loneliness/isolation & $\square$ & $\square$ & $\square$ & $\square$ & $\square$ & $\square$ & $\square$ & $\square$ & $\square$ & $\square$ & $\square$ & $\square$ & $\square$ & $\square$ & $\square$ \\
\hline Prejudice & $\square$ & $\square$ & $\square$ & $\square$ & $\square$ & $\square$ & $\square$ & $\square$ & $\square$ & $\square$ & $\square$ & $\square$ & $\square$ & $\square$ & $\square$ \\
\hline Relationship difficulties & $\square$ & $\square$ & $\square$ & $\square$ & $\square$ & $\square$ & $\square$ & $\square$ & $\square$ & $\square$ & $\square$ & $\square$ & $\square$ & $\square$ & $\square$ \\
\hline Inability to socialise & $\square$ & $\square$ & $\square$ & $\square$ & $\square$ & $\square$ & $\square$ & $\square$ & $\square$ & $\square$ & $\square$ & $\square$ & $\square$ & $\square$ & $\square$ \\
\hline
\end{tabular}

\begin{tabular}{|c|c|c|c|c|c|c|c|c|c|c|c|c|c|c|c|}
\hline \multirow[b]{2}{*}{ External stressors } & \multirow[b]{2}{*}{ Never } & \multirow[b]{2}{*}{ Rarely } & \multirow[b]{2}{*}{ Sometimes } & \multirow[b]{2}{*}{ Often } & \multirow[b]{2}{*}{ Always } & \multicolumn{9}{|c|}{ Not severe } & \multirow{2}{*}{$\begin{array}{l}\text { Severe } \\
10\end{array}$} \\
\hline & & & & & & 1 & 2 & 3 & 4 & 5 & 6 & 7 & 8 & 9 & \\
\hline Financial strain & $\square$ & $\square$ & $\square$ & $\square$ & $\square$ & $\square$ & $\square$ & $\square$ & $\square$ & $\square$ & $\square$ & $\square$ & $\square$ & $\square$ & $\square$ \\
\hline Change in residence & $\square$ & $\square$ & $\square$ & $\square$ & $\square$ & $\square$ & $\square$ & $\square$ & $\square$ & $\square$ & $\square$ & $\square$ & $\square$ & $\square$ & $\square$ \\
\hline Job dissatisfaction & $\square$ & $\square$ & $\square$ & $\square$ & $\square$ & $\square$ & $\square$ & $\square$ & $\square$ & $\square$ & $\square$ & $\square$ & $\square$ & $\square$ & $\square$ \\
\hline Legal difficulties & $\square$ & $\square$ & $\square$ & $\square$ & $\square$ & $\square$ & $\square$ & $\square$ & $\square$ & $\square$ & $\square$ & $\square$ & $\square$ & $\square$ & $\square$ \\
\hline Other (specify below) & $\square$ & $\square$ & $\square$ & $\square$ & $\square$ & $\square$ & $\square$ & $\square$ & $\square$ & $\square$ & $\square$ & $\square$ & $\square$ & $\square$ & $\square$ \\
\hline
\end{tabular}


8. Indicate how you cope with stress and relax during a typical month. A list of techniques is provided at the bottom, feel free to add others that you use. List any that apply and indicate on a scale of 1-5 how effective the technique is at helping you relax.

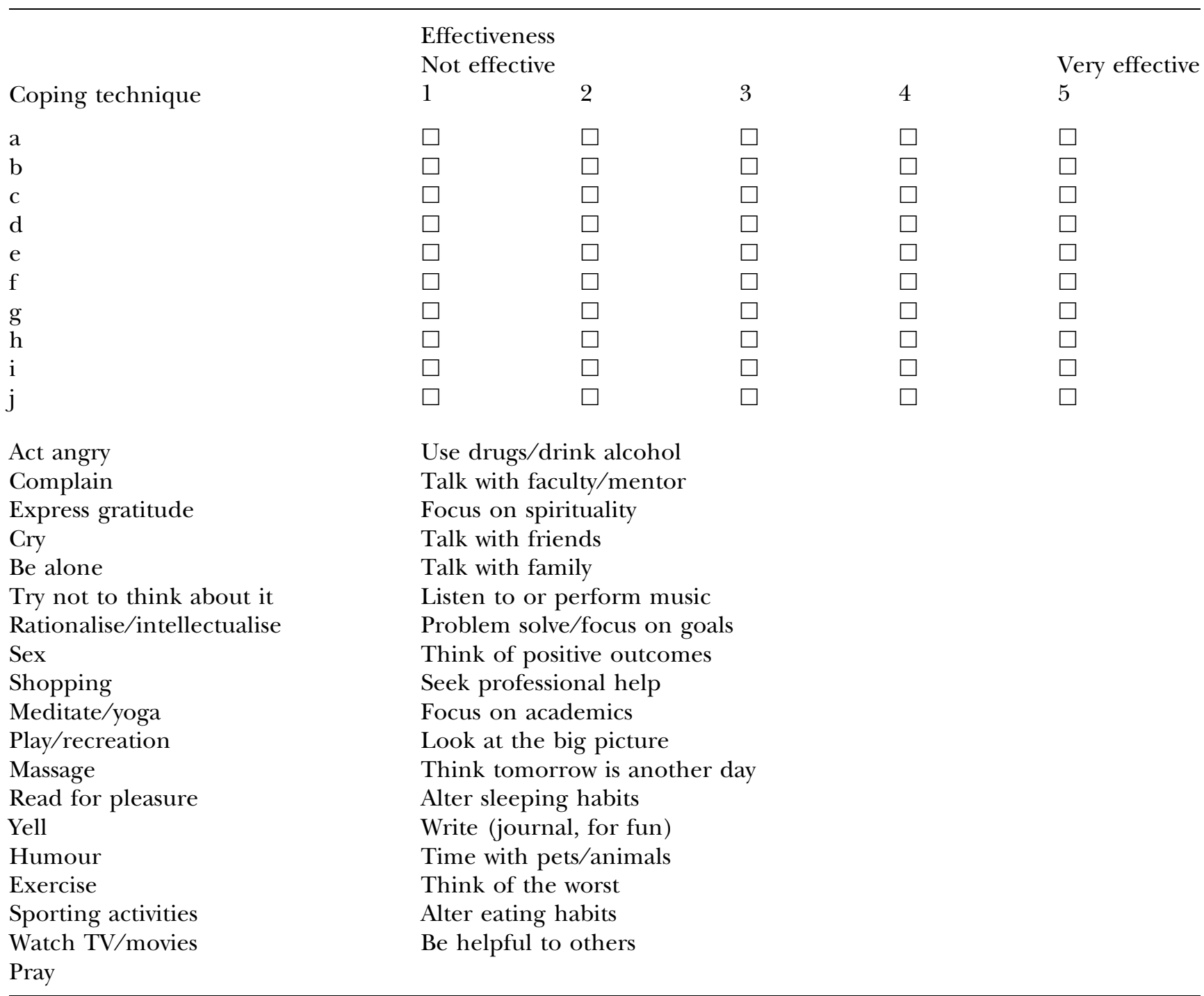

Part II

EXERCISE

1. Please list the types of exercise you engage in regularly. For each type, indicate how frequently you engage in that exercise (frequency) and for how long you have consistently participated in the exercise (persistence).

\begin{tabular}{|c|c|c|c|c|c|c|c|c|c|c|}
\hline \multirow{7}{*}{ Type of exercise } & \multicolumn{5}{|c|}{ Coping technique } & \multicolumn{5}{|c|}{ Effectiveness } \\
\hline & Monthly & Bi-weekly & $\begin{array}{l}1-2 x \\
\text { /week }\end{array}$ & $\begin{array}{l}3-5 \times \\
\text { /week }\end{array}$ & Daily & $\begin{array}{l}<8 \\
\text { times }\end{array}$ & $\begin{array}{l}3-6 \\
\text { month }\end{array}$ & $\begin{array}{l}6 \text { mo- } \\
1 \text { year }\end{array}$ & $\begin{array}{l}1-2 \\
\text { years }\end{array}$ & $\begin{array}{c}>2 \\
\text { years }\end{array}$ \\
\hline & $\square$ & $\square$ & $\square$ & $\square$ & $\square$ & $\square$ & $\square$ & $\square$ & $\square$ & $\square$ \\
\hline & $\square$ & $\square$ & $\square$ & $\square$ & $\square$ & $\square$ & $\square$ & $\square$ & $\square$ & $\square$ \\
\hline & $\square$ & $\square$ & $\square$ & $\square$ & $\square$ & $\square$ & $\square$ & $\square$ & $\square$ & $\square$ \\
\hline & $\square$ & $\square$ & $\square$ & $\square$ & $\square$ & $\square$ & $\square$ & $\square$ & $\square$ & $\square$ \\
\hline & $\square$ & $\square$ & $\square$ & $\square$ & $\square$ & $\square$ & $\square$ & $\square$ & $\square$ & $\square$ \\
\hline
\end{tabular}


2. Please list the reasons you exercise. Common reasons include stress relief, health benefits, weight loss, etc. If you DO NOT exercise, please indicate reasons why you do not exercise.

\section{EATING}

3. How many days per week, on average, do you eat breakfast?

\section{$\square 1 \square 2 \square 3 \square 4 \square 5 \square 6 \square 7$}

4. How many days per week, on average, do you eat at least 1 nutritious meal?

$\square 1 \square 2 \square 3 \square 4 \square 5 \square 6 \square 7$

5. How many times per day, on average, do you eat?

$\square 1 \square 2 \square 3 \square 4 \square 5 \square 6 \square 7$

6. Do you ever purposefully purge your food?

$\square$ Yes $\square$ No

7. Do you ever consciously monitor or restrict your intake of food? (to restrict saturated fats, cholesterol, sodium, or calories)

$\square$ Yes $\square$ No

8. How would you characterise your weight?

$\square$ overweight $\square$ about the right weight $\square$ underweight

\section{SLEEP}

9. How many hours of sleep do you get per night, on average?

$\square 4$ or less $\square 5 \square 6 \square 7 \square 8 \square 9 \square 10$

10. When you wake up in the morning, do you feel well refreshed?

$\square$ Yes $\square$ No

11. How many times per quarter do you attend class OR engage in other work/school activities when you feel ill enough to stay home?

$\square$ never $\square$ at least $1 \square 2-3 \square 4-5 \square>5$

\section{SEXUAL BEHAVIOURS}

12. When engaging in sexual activity, do you use condoms?

$\square$ Yes $\square$ No $\square$ not applicable

13. If you engage in sexual intercourse, what method of birth control do you use, if any (please list)?

14. How many sexual partners have you had in the last year? 
15. How often do you use drugs or alcohol before having sex?

$\square$ never $\square$ occasionally $\square$ frequently $\square$ always

\section{SOCIAL SUPPORT}

16. How often do you feel you receive adequate emotional support?

$\square$ never $\square$ rarely $\square$ sometimes $\square$ often $\square$ always

17. How often are you comfortable going to others for emotional support?

$\square$ never $\square$ rarely $\square$ sometimes $\square$ often $\square$ always

18. How often are you satisfied with the emotional support received from others?

$\square$ never $\square$ rarely $\square$ sometimes $\square$ often $\square$ always

19. How many people do you feel you can tell almost anything to, people you can count on for understanding or support?

$\square 0 \square 1 \square 2 \square 3 \square 4 \square 5$ or more

Part III

1. How many different times in your life have you had a period where you felt sad or blue for at least 2 weeks? $\square 0 \square 1 \square 2 \square 3 \square 4 \square 5$ or more

2. How often have you experienced any of the following during the past 4 weeks?

\begin{tabular}{|c|c|c|c|c|}
\hline & Never & $\begin{array}{l}\text { 1-3 times } \\
\text { weekly }\end{array}$ & $\begin{array}{l}\text { Most days } \\
\text { per week }\end{array}$ & $\begin{array}{l}\text { Nearly every } \\
\text { day for } 2 \text { weeks }\end{array}$ \\
\hline Felt sad, low in spirits or depressed & $\square$ & $\square$ & $\square$ & $\square$ \\
\hline Appetite was less than or greater than usual & $\square$ & $\square$ & $\square$ & $\square$ \\
\hline Gained or lost weight without trying & $\square$ & $\square$ & $\square$ & $\square$ \\
\hline Had difficulty falling asleep or sleeping too much & $\square$ & $\square$ & $\square$ & $\square$ \\
\hline Trouble thinking, concentrating, or making decisions & $\square$ & $\square$ & $\square$ & $\square$ \\
\hline Felt hopeless or worthless & $\square$ & $\square$ & $\square$ & $\square$ \\
\hline Thought about death or suicide & $\square$ & $\square$ & $\square$ & $\square$ \\
\hline Thought about a specific way to commit suicide & $\square$ & $\square$ & $\square$ & $\square$ \\
\hline
\end{tabular}


Part IV

Consult the following list of drugs and indicate the frequency with which you use each one. $(1=$ no use, $5=$ daily use)

\begin{tabular}{|c|c|c|c|c|c|}
\hline & No use & $\begin{array}{l}\text { A few times } \\
\text { per year }\end{array}$ & $\begin{array}{l}\text { A few times } \\
\text { per month }\end{array}$ & $\begin{array}{l}\text { A few times } \\
\text { per week }\end{array}$ & Daily use \\
\hline Alcohol & $\square$ & $\square$ & $\square$ & $\square$ & $\square$ \\
\hline Amphetamines (speed, uppers) & $\square$ & $\square$ & $\square$ & $\square$ & $\square$ \\
\hline Barbiturates (blues, rods) & $\square$ & $\square$ & $\square$ & $\square$ & $\square$ \\
\hline Caffeine & $\square$ & $\square$ & $\square$ & $\square$ & $\square$ \\
\hline Cocaine & $\square$ & $\square$ & $\square$ & $\square$ & $\square$ \\
\hline Crystal methamphetamine & $\square$ & $\square$ & $\square$ & $\square$ & $\square$ \\
\hline Diet pills & $\square$ & $\square$ & $\square$ & $\square$ & $\square$ \\
\hline Ecstasy & $\square$ & $\square$ & $\square$ & $\square$ & $\square$ \\
\hline GHB, rohypnol & $\square$ & $\square$ & $\square$ & $\square$ & $\square$ \\
\hline Hallucinogens (mushrooms, LSD, PCP) & $\square$ & $\square$ & $\square$ & $\square$ & $\square$ \\
\hline Herbal supplements & $\square$ & $\square$ & $\square$ & $\square$ & $\square$ \\
\hline Nicotine & $\square$ & $\square$ & $\square$ & $\square$ & $\square$ \\
\hline Marijuana & $\square$ & $\square$ & $\square$ & $\square$ & $\square$ \\
\hline Metabolic supplements (ephedrine, etc.) & $\square$ & $\square$ & $\square$ & $\square$ & $\square$ \\
\hline Opiates (morphine, heroin, etc.) & $\square$ & $\square$ & $\square$ & $\square$ & $\square$ \\
\hline Sleeping aids (to aid with sleeping) & $\square$ & $\square$ & $\square$ & $\square$ & $\square$ \\
\hline Steroids & $\square$ & $\square$ & $\square$ & $\square$ & $\square$ \\
\hline Tranquillisers (Librium, valium, ketamine) & $\square$ & $\square$ & $\square$ & $\square$ & $\square$ \\
\hline Waking aids (to aid in staying awake) & $\square$ & $\square$ & $\square$ & $\square$ & $\square$ \\
\hline
\end{tabular}

1. On a typical occasion of alcohol consumption, how much do you consume?

$\square$ none $\square$ 1-3 drinks $\square$ 4-5 drinks $\square 7-10$ drinks $\square 11$ or more drinks

2. How many cigarettes do you smoke per day?

$\square$ none $\square$ 1-4 cigarettes $\square 5$-10 cigarettes $\square$ 11-20 cigarettes $\square$ more than 1 pack of cigarettes 